\section{Ideal Home Exhibition}

THE nineteenth Daily Mail Ideal Home Exhibition will open at Olympia, London, on March 26. A feature of the Grand Hall will be the great murals, $36 \mathrm{ft}$. high and $374 \mathrm{ft}$. long, from end to end of each side of the hall. The eighteen panels will bring to the eye, not only the vivid story of the changing world but also the actual features of more than a thousand men and women-pioneers, social workers, explorers, scientific workers, engineers, industrialists and others who have achieved distinction in helping to change the world for the better. This work has been carried out to the original designs of Oswald Cuningham. Among the features of the Exhibition will be a $£ 50,000$ installation of the very latest types of British-made canning machinery, weighing nearly 40 tons, to demonstrate the rapid strides made by this new home industry. Twenty-five years of progress in things engineering and scientific will be found on the second floor of the Empire Hall-the development of electric lighting, telephones, aviation, travel, transport, sound-recording, reproduction and radio. The General Post Office will have in operation the latest of the many wonderful machines utilised in modern communications. The strides made by 'staybrite' steel, which made its debut at the exhibition last year, will be demonstrated, and there will be numerous exhibits of beauty and utility for the home for furnishing, lighting, heating, decoration, labour-saving and recreation.

\section{Improving Long-Distance Telephone Transmission}

THE rapid improvement of the technique of radio communication during the last ten years is now having a beneficial influence in the development of long-distance telephone transmission. In particular, the improvements made in vacuum valves due to the demands made by broadcasting engineers have led directly to great improvements in the design of the repeater valves used in long-distance telephony. It is well known that during conversation over long lines by means of carrier frequency equipment the sounds heard sometimes vary greatly in loudness. This is attributed to the fact that the attenuation of the line, especially when overhead wires are used, changes with climatic conditions, temperature, etc. With cable circuits, the loudness remains much more constant. The phenomenon is analogous to the well-known phenomenon of 'fading' in radio trans. mission. Successful attempts have recently been made to mitigate this trouble. A paper by H. Sterky and R. Stalemark which appears in Ericsson Technics, No. 3, 1934, describes an automatic method of compensating for these variations which has been used in practice for the last two years with good results. The development of the method is due to the telephone firm of Ericsson, Stockholm. It depends on the well-known mathematical theorem that a carrier wave modulated by a wave of voice frequency is equivalent to three separate simultaneous oscilla. tions. One of these has the frequency of the carrier wave; the others, called side-band waves, are of higher and lower frequency respectively. In the
Ericsson device, during conversation, the carrier and one side-band wave are transmitted. Signalling is done by modulating the carrying wave with the 'ringing' current. It is stated that the volume control of the sound obtained in this way is very good.

\section{Shellfish and the Public Health}

THE Minister of Health has issued an Order, Public Health (Shell-fish) Regulations, 1934, revoking previous regulations, and regulating the sale of shellfish for human consumption, which came into operation on January 1. The new regulations give powers to local authorities to investigate suspected layings, to prohibit the sale of shellfish from polluted layings, and to provide cleansing apparatus if considered necessary (Statutory Rules and Orders, 1934, No. 1342. 2d. Circular 1446. Id. H.M. Stationery Office).

\section{International Office for the Protection of Nature}

THE Belgian Government has by Royal decree officially recognised the International Office for the Protection of Nature, Rue Montoyer 21, Brussels, and has appointed the following delegates to be its representatives on the General Council of the Office : Delegates for Belgium, Baron E. de Cartier de Marchienne, Belgian Ambassador in London, and Count Henry Carton de Wiart, former Prime Minister ; Delegates for the Belgian Congo and the Mandated Territory of Ruanda-Urundi, P. Charles, Minister of Colonies, and Prof. V. Van Straelen, director of the Royal Belgian Museum of Natural History and president of the Institute for National Parks in the Belgian Congo.

\section{Oxidation-Reduction Potentials in Bacteriology}

THE fact that a second edition of Dr. L. F. Hewitt's monograph on "Oxidation-Reduction Potentials" has been found necessary indicates the interest taken by biologists in the subject ("Oxidation-Reduction Potentials in Bacteriology and Biochemistry" : published by the London County Council. Pp. 81. 2s.). Since the first edition was noticed in our columns (NATURE, 128, $73 ; 1931$ ) the subject has advanced steadily, and the author has taken the opportunity to revise and extend the text and bring the bibliography up to date. The study of electrode potentials is proving of assistance in the practical question of the rationalisation of culture media and cultural conditions, and is throwing light upon the biological behaviour of organisms, such as the maintenance or loss of virulence, questions of great importance in medical practice.

\section{Improvement of Grassland}

As much as eighteen million acres in England and Wales consists of grassland, and considerable attention has been paid in recent years to its improvement. The need for authoritative information on this important subject led to the publication of Bulletin No. 3, "The Improvement of Grassland", by the Ministry of Agriculture and Fisheries, a fourth and revised edition of which has been issued (1s. net). The revision of the text has largely been carried out by Prof. J. A. Hanley (Armstrong College, Newcastle- 
upon-Tyne) who has taken the opportunity of incorporating in the present issue the deductions drawn from the work done under the Ministry's 'Grassland Campaign', and also to include a section on the comparatively new system of rotational or 'managed' grazing. The sections on the renovation of wornout grassland and seed-sowing remain substantially as written by Prof. R. G. Stapledon, of the Plant Breeding Station, Aberystwyth.

\section{Medical Research in South Africa}

Trwe annual report by the director, Sir Spencer Lister, of the South African Institute for Medical Research, Johannesburg, gives an account of the routine and research work of the Institute for the year 1933. Concentrated anti-plague serum, prepared in the Serum Department, has been tested experimentally, and has been found to have four times the protective and curative power of the unconcentrated serum, concentration being in the same ratio. Considerable difficulty has been experienced in maintaining the virulence of the plague bacillus in culture, and this difficulty has not yet been overcome. The study of pneumonia as it occurs among native miners of the Witwatersrand goldfields was continued, and the work confirms previous findings that the disease is not a pure pneumococcus pneumonia of the earlier days of the Rand, but that other organisms are associated with, or replace, the pneumococcus, namely, the streptococeus, staphylococcus and influenza bacillus. During the year, a case of human rabies due to a cat bite was observed; the incidence of human rabies infection is on the increase in South Africa, being conveyed by the cat, the tame meercat, and occasionally the dog. The observations upon dust estimation and control in the mines have been extended, and research upon several other subjects has been continued.

\section{Astronomical Phenomena in March}

Mercury is now a morning object, and attains its greatest elongation of $28^{\circ} \mathrm{W}$. on March 15. Venus, on the other hand, is moving round to its greatest eastern elongation $\left(45^{\circ} \mathrm{E}\right.$. on June 30$)$ and has already become a conspicuous object in the evening sky just after sunset. Mars is well placed for observation, being very nearly in opposition. Jupiter is a morning object, and Saturn is very near the sun. An interesting conjunction of Venus and Uranus will occur on March 22 at 7 hours, when the planets will only be separated by $0 \cdot 4^{\circ}$. This conjunction will, of course, be invisible in England, but the two planets should be seen close together, in a small telescope, on the evening of March 21 or of March 22. Neptune is well placed for telescopic observation, being in opposition to the sun on March 4.

\section{Announcements}

Prof. W. J. DE HaAs, University of Leyden, informs us by cable that on February 15 he succeeded in reaching a temperature only five thousandths $(0.005)$ of a degree above absolute zero. Particulars of this remarkable achievement will be awaited with great interest.
AT the annual meeting of the Royal Society for the Protection of Birds to be held at the Westminster Palace Rooms, 44 Victoria Street, S.W.1, on Friday, March 1, Her Grace the Duchess of Portland, president of the Society, in the chair, a motion will be submitted "That the Governments of all maritime nations be urged to give the strongest possible support to the League of Nations in their endeavours to secure the universal adoption of effective measures for preventing the pollution of the seas by oil".

IT is proposed to hold an exhibition of English periodicals and reviews in the library of the University of Coimbra, Portugal, early this year. It is hoped later to transfer the exhibition to Lisbon, Oporto and Braga. It appears that English is the second foreign language in Portugal, and a large proportion of its inhabitants have a working knowledge of the language ; but there is a general ignorance of what periodicals and reviews are published in English. It is hoped that the exhibition will remedy this state of affairs. Further information can be obtained from the Director, Biblioteca da Universidade, Coimbra, Portugal.

Referring to Mr. C. R. Cosens's letter in Nature of January 12 (p. 71) on "Designation of Logarithms to Base e", Dr. J. Satterly, of the University of Toronto, writes: "Long ago I decided that logh was too long and $\log _{10}$ and $\log _{e}$ awkward and have recently designated for blackboard work common logarithms and natural logarithms as 'ln' and 'lc', pronounced something like 'Ellen' and 'Elsie' respectively."

A BOoKLET dealing with the chloramine group of antiseptics has been issued by Boots Pure Drug Co., Ltd., Station Street, Nottingham, from whom it may be obtained free of charge. Attention is directed to the use of 'chloramine- $T$ ' and 'dichloramine- $T$ ' in the treatment of infected wounds, and to 'halazone', a most satisfactory chlorine compound for the sterilisation of drinking water.

Applicatrons are invited for the following appointments, on or before the dates mentioned :-A computer (class II) to the Ordnance Committee, Royal Arsenal, Woolwich, S.E.18 - The Secretary (Feb. 25). A lecturer in electrical engineering at Chesterfield Technical College-The Director of Education, County Education Office, St. Mary's Gate, Derby (Feb. 25). A University lecturer and a part-time University lecturer in the Faculty of Mathematics, University of Cambridge-The Secretary to the Faculty Board of Mathematics, St. John's College, Cambridge (March 2). Junior scientific officers in the Aerodynamics and Radio Departments of the National Physical Laboratory, Teddington-The Director (March 4). A resident lecturer (chemistry or physics) at Girton College, Cambridge (March 6). An assistant lecturer in zoology in the University of Bristol-The Secretary (March 11). A Henry George Plimmer fellowship in pathology at the Imperial College of Science and Technology, Prince Consort Road, London, S.W.7-The Rector (June 17). 